\title{
Kvinders \\ integration \\ i akademiet
}

er der i de seneste år udkommet en række afhandlinger, som historisk skildrer kvinders integration eller mangel på samme $\mathrm{i}$ universitetsverdenen. Tord Rönnholms: Kunskapens kvinnor. Sekelskiftets studentskor $i$ mötet med den manliga universitetsvärlden fra 1999 analyserer den første periode fra 1873 frem til 1914, hvor de kvindelige studerende efterhånden udgjorde 10 pct. af de studerende. Rönnholm har set nærmere på, hvem de var, og han har undersøgt, hvordan systemet tog imod dem, ved at analysere universitetets og politikernes debat vedrørende kvinders adgang til at studere. Endvidere rummer afhandlingen et mentalitetshistorisk studium af de kvindelige studerende, deres syn på sig selv og fremtiden, og deres forhold til de mandlige studerende.

Universitetet var definitivt ikke et sted for kvinder ifølge Rönnholms analyse. De var meget lidt velkomne. Der fandtes dog en gruppe med en liberal holdning, som 
betragtede kvinden som medborger, som et individ $\mathrm{i}$ et begyndende urbaniseret og industrielt samfund, hvor der var brug for alle kræfter. Disse grupper repræsenterede det borgerlige meritokratiske princip, ${ }^{1}$ hvor kompetence blev sat før køn og arv, og hvor den abstrakte lighed, det vil sige den civile medborgerskabside, herskede. Rönnholm påpeger, at det er i lyset af forandringen fra en religiøs til en videnskabelig diskurs, at vi må se modstanden mod kvindelige akademikere. I slutningen af 1800-tallet fik de naturvidenskabelige argumenter imidlertid legitimitet, i takt med at biologien havde succes. Videnskabelige argumenter var en mere moderne indpakning af kønsdominansforholdet, og argumenterne blev hentet i kønnenes biologiske forskelle. At definere kvinder som seksuelle væsner og betone det kropslige hos dem var en brugt disciplineringsmetode.

Det offentlige rum var fortsat det mandlige rum, som kvinder kun fik begrænset adgang til. De dannede derfor deres egne organisationer og traditioner i Sverige i modsætning til i Danmark. Det er imidlertid også en pointe, at de kvindelige studerende ikke ville se deres situation som begrænset. I deres egne biografier nedtones, ifølge Rönnholm, spørgsmålet om diskrimination. Han fremhæver, at undersøgelser fra England tyder på det samme, nemlig at kvindelige akademikere til nød erkender, at kvinder som gruppe var diskrimineret, men ikke som enkeltindivider. Det var meget få, som talte åbent om disse ting, og det ville således også have været ensbetydende med at problematisere universitetets selvforståelse som et neutralt rum.

'En frusen ideologi' gennemsyrer universiteterne ifølge Hanna Markusson Winkvist, som har skrevet afhandlingen Som isolerade öar. De lagerkransade kvinnorna och akademien under 1900-talets första hälft fra 2003. Formelle regler kan ændre sig, men holdningerne fortsætter, hvilket de 104 kvinder i Sverige, som disputerede mellem 1870 og 1949, fik at mærke. Markusson kortlægger deres sociale baggrund og netværk og forsøger at finde ud af, hvad der blev af dem. Kun én blev professor, resten søgte andre steder hen: Ud i skolen og journalistikken. Det lykkedes således ikke for dem at slå igennem. De var som isolerede øer, afvigere, anomalier, der hele tiden blev problematiseret. Det er en deprimerende historie, men på langt sigt kunne kvinder ikke stoppes, og mænd kunne ikke bevare monopolet. Markusson påpeger, at de kvindelige studerende selv identificerede sig med det mandlige, og det svækkede deres position på xgteskabsmarkedet. Både i Sverige og i Danmark var en betydeligere højere andel af akademiske kvinder ugifte end befolkningen i øvrigt.

Helt frem til 1970 var det den udbredte diskurs, at kvinder ikke hørte hjemme på et universitet, ifølge Lina Carls' Våp eller nucka? Kvinnors högre studier och genusdiskursen 1930-1970 fra 2004. Med afhandlingen undersøges, hvordan den svenske kønsdiskurs formedes i debatten om kvinder og højere uddannelser i perioden 1930 til 1970. Carls har undersøgt, hvorfor kvinders integration på universitetet er gået så langsomt, og hvordan henholdsvis de kvindelige og de mandlige studerende er skildret i forskellige former for diskurser. Carls har fulgt den lokale debat i Lund og Uppsala gennem en analyse af studenterblade, studenterforeninger og studenterromaner. Ser vi på udviklingen $\mathrm{i}$ tal, så skete der $\mathrm{i}$ Sverige et spring fra ca. 15 pct. kvindelige studerende omkring 1930 til 40 pct. omkring 1970. Men på trods af denne kvantitative forandring var diskursen nærmest den samme: Kvinder hørte ikke rigtig hjemme på et universitet.

Endnu i 1950'erne, da man i Sverige alvorligt diskuterede, hvordan man kunne rekruttere flere unge til universitetet, så man ikke kvinder men kun mænd som en reserve og vendte derfor blikket mod arbejderklassens mænd. Der var eksempler på modstand imod den hegemoniske kønsdiskurs, og modstanden kom overvejende fra kvin- 
delige studerende. Særligt blandt mandlige akademikere, politikere og journalister blev kvinden set på som forskellig fra manden, og formålet med hendes studier blev hele tiden problematiseret. Hun blev set på som nar eller gammeljomfru, våp eller nucka, jf. bogens titel. Kvindelighed og studier hang ikke sammen. Kvinders manglende kapacitet blev demonstreret i mange sammenhænge af både professorerne og de mandlige studerende. Med Pierre Bourdieu kan dette kaldes en slags symbolsk vold, ifølge Carls. Til dette hørte fordomme om, at kvinden var mere interesseret i læreren end i studierne, at hun primært var interesseret $\mathrm{i}$ at finde en mand, og at hun egnede sig bedre til kontor- og husarbejde end til intellektuel virksomhed. Diskursen var kort og godt den, at kvinder og mænd var forskellige, at kvinders sundhed tog skade af intellektuel virksomhed, og at ægteskab og studier var uforenelige. Og alligevel kan man ane forandringer bag den træge diskurs, nemlig at kvinder begynder at blive betragtet som konkurrenter i den akademiske verden i 1930'erne, at mulighederne for kvinder udvides i 1950'erne, og at debatten ændrer karakter i løbet af 1960'erne. Ingen tvivl om at universitetet er en institution, som holder fast i traditionerne.

Carls benytter diskursbegrebet, men er opmærksom på forandringspotentialet og forsøger at give plads til de historiske aktører. Kønsbegrebet er inspireret af Yvonne Hirdmans teori om genus og Bourdieus teori om den mandlige dominans, men for at give aktørerne mere plads henter Carls inspiration hos Nancy Fraser, som taler om en mangfoldighed af diskurser, og at kvinder selv har medvirket til at forandre diskursen. Frasers pragmatiske synspunkt består $i$, at når tilstrækkeligt mange protesterer imod det traditionelle synspunkt, at kvinder og mænd er forskellige, kan den eksisterende orden brydes, og der sker forandringer. Spørgsmålet er så, i hvilket omfang og hvornår det skete på universitetet? Carls konklusion er desværre, at Hirdman og Bourdieu snarere end Fraser har ret. Strukturerne er enormt seje, og køn og mandsdominansen så faste, at de sjældent problematiseres. Traditionens magt synes at være mere sej end lovgivningens forandringsambitioner.

En enkelt finsk undersøgelse vil jeg også gerne præsentere ved denne lejlighed. Finland skildres ofte som 'the promised land' for akademiske kvinder. Sociologen Liisa Husu udgav i 2001 Sexism, Support and Survival in Academia. Academic Women and hidden Discrimination in Finland, som bygger på over 100 interviews og beretninger fra kvinder på 11 finske universiteteter. Husu ser på akademiske kvinders oplevelse af kønsdiskrimination, støtte og overlevelsesstrategier, ud fra en teoretisk ramme udviklet på baggrund af Joan Ackers teori om kønnede organisationer. Kvinderne kom tidligt ind på universiteterne i Finland, og der er i dag en meget høj andel af kvinder. Alligevel fandt Husu, at strukturerne og kulturen er kønnet. Diskrimination er ikke noget, der tales særligt højt om. Måske kan man til nød indrømme, at der strukturelt findes diskrimination, mens det er meget sværere at indrømme det personligt. Med en undersøgelse som sikrede anonymitet, var det dog muligt at komme bag om de strukturelle forhold og påvise den skjulte diskrimination og sexisme. I et foredrag har Husu fortalt, at når båndoptageren var slukket, og hun var på vej ud af døren, så kunne flere af de interviewede alligevel huske episoder, hvor de havde følt sig diskrimineret. Diskrimination er det meget upassende at tale om i en institution, hvis brand er neutralitet og objektivitet, men at den findes dokumenteres såvel i historiske som sociologiske undersøgelser.

Ud over de nævnte værker kan også henvises til Förbjuden frukt på kunskapens träd: Kvinnliga akademiker under 100 àr fra 2004 og Kvinnor vid Lunds universitet. 


\section{Note}

1. Det meritokratiske princip er princippet om, at den bedst kvalificerede tildeles mest ansvar og magt, flest pligter, og hvad der deraf følger af prestige, titler og privilegier.

\section{LITTERATUR}

- Blomqvist, Göran \& Wetterberg, Christina Carlsson (red.) (2000): Kvinnor vid Lunds universitet. Lund University Press, Lund.

- Carls, Lina (2004): Våp eller nucka? Kvinnors högre studier och genusdiskursen 1930-1970. Nordic Academic Press, Lund.

- Haneson, Britt-Marie Fridh \& Haglund, Ingegerd (red.) (2004): Förbjuden frukt på kunskapens träd: Kvinnliga akademiker under 100 àr. Atlantis, Stockholm.
- Husu, Liisa (2001): Sexism, Support and Survival in Academia. Academic Women and hidden Discrimination in Finland. Department of Social Psychology, University of Helsinki, Helsingfors. - Markusson Winkvist, Hanna (2003): Som isolerade öar. De lagerkransade kvinnorna och akademien under 1900-talets första hälft. B. Österlings bokförlag Symposion, Eslöv.

- Rönnholm, Tord (1999): Kunskapens kvinnor. Sekelskiftets studentskor $i$ mötet med den manliga universitetsvärlden. Institutionen för historiska studier vid Umeå Universitet, Umeå.

Bente Rosenbeck, cand.mag., dr.phil.

Kønsstudier

Nordiske studier og sprogvidenskab

Det Humanistiske Fakultet

Københavns Universitet 